\title{
Water productivity with localized irrigation using groundwater and reuse water in the cultivation of plant species
}

\author{
Antônia B. M. Macêdo ${ }^{1}$, Raimundo N. T. Costa ${ }^{1}$, Danielle F. de Araújo ${ }^{2}$ \& Kenya G. Nunes ${ }^{1}$ \\ ${ }^{1}$ Universidade Federal do Ceará/Departamento de Engenharia Agrícola, Fortaleza, CE, Brasil. E-mail: ufcgpeas@gmail.com (Corresponding author) - \\ ORCID: 0000-0003-0858-7101; rntcosta@ufc.br - ORCID: 0000-0001-6245-7768; kenyagn@gmail.com - ORCID: 0000-0001-8996-1497 \\ ${ }^{2}$ Universidade de Fortaleza, Fortaleza, CE, Brasil. E-mail: dannyellearaujo@gmail.com - ORCID: 0000-0002-9649-9875
}

\begin{abstract}
This study aimed to analyze the water saving potential of replacing the traditional, furrowirrigated banana crop in the Curu-Pentecoste Irrigated Perimeter with localized systems by inserting new cropping plans and sources of groundwater and reuse water. An analysis of the support capacity in shallow tube wells for irrigation was also performed, considering the scenario of full recharge and water scarcity. The economic analysis was performed using the profitability indicators of the investment analysis: benefit/ cost ratio, net present value, internal rate of return and payback period. Water productivity data reveal that cropping plans associated with alternative sources of water from shallow tube wells and reuse of the excess surface irrigation water in localized systems are economically more attractive than traditional, furrow-irrigated banana crop. The support capacity of shallow tube wells reveals that the exploitation of this underground water resource in the region is a viable alternative for irrigation of small areas. With the exception of banana, the other scenarios analyzed showed positive cash flows from the second year.
\end{abstract}

Key words: water saving, underground water, water sustainability

\section{Produtividade da água com irrigação localizada utilizando águas subterrâneas e de reúso no cultivo de espécies vegetais}

RESUMO: Objetivou-se neste estudo analisar o potencial de economia de água da substituição do cultivo tradicional da bananeira irrigada por sulcos no Perímetro Irrigado Curu-Pentecoste por sistemas localizados mediante a inserção de novos planos de ocupação e fontes de água subterrânea e de reúso. Realizou-se, também, análise da capacidade de suporte em poços rasos tubulares para irrigação, considerando o cenário de recarga plena e de escassez hídrica. A análise econômica foi realizada por meio dos indicadores de rentabilidade da análise de investimento: relação benefício/custo, valor presente líquido, taxa interna de retorno e período payback. Os dados de produtividade da água revelam que os planos de cultivo associados às alternativas de fontes hídricas provenientes de poço raso tubular e de reúso do excesso da irrigação por superfície em sistemas localizados são mais atrativos do ponto de vista econômico que o cultivo tradicional da bananeira irrigada por sulcos. A capacidade de suporte dos poços rasos tubulares revela que a exploração deste recurso hídrico subterrâneo na região é alternativa viável para irrigação de pequenas áreas. À exceção da bananeira, os demais cenários analisados demonstraram fluxos de caixa positivos a partir do segundo ano.

Palavras-chave: economia de água, água subterrânea, sustentabilidade hídrica 


\section{INTRODUCTION}

Expansion of agriculture and industry and the degradation of the environment are pointed out as the main factors responsible for reducing the available volume and quality of water, which justifies the need for using efficient irrigation methods and alternative sources of water resources, especially in arid and semiarid regions (Rebouças et al., 2010).

The continuity of agricultural development requires new strategies, with a view to increasing crop yield and reducing production risks. Considering the need to preserve water resources and the environment, modern agriculture needs to increase the yield and quality of products in a sustainable way. In this context, the production system, including irrigation efficiency, should be analyzed and the planning should indicate the best management plan (Bonini et al., 2014; Dantas et al., 2014; Malek et al., 2018).

Crops, the medium and the different management practices can influence the relationship between agricultural production and water consumption, defining water productivity for a crop as the ratio existing between the quantity produced and the amount of water applied to obtain such production. It is also worth highlighting that water productivity decreases with the increase in the water factor, a behavior due to the reduction in the rate of water utilization by the crop (Perry et al., 2009; Nunes et al., 2017).

Currently, irrigation with treated wastewater is recurrent in agriculture, especially in arid and semiarid areas, as it is a water resource that is sustainable and available in all seasons, which can ensure the maintenance of agricultural activity (Vergine et al., 2017; Leuther et al., 2018).

Coconut is the main crop of the Curu-Pentecoste Irrigated Perimeter, totaling approximately $50 \%$ of the area cultivated in each agricultural lot, and farmers are not interested in its replacement. Conversely, the furrow-irrigated banana crop has low water productivity, and most farmers are interested in replacing it with more profitable crops.

In view of the above, the hypothesis considered was that changes in the cropping plans of the cultivated area, irrigation method and use of water resources would enable the continuity of agricultural activity and the increase in water productivity, being economically viable. The objective of this study was to analyze the water saving potential of replacing traditional, furrow-irrigated banana crop in the Curu-Pentecoste Irrigated Perimeter with localized irrigation systems by inserting new cropping plans and sources of groundwater and reuse water.

\section{Material ANd Methods}

The study was carried out in the Curu-Pentecoste Irrigated Perimeter, belonging to the Curu River Basin, in the State of Ceará, Brazil, from 2012 to 2014, whose area of coverage is
1068 ha, with infrastructure of irrigation for common use. According to Köppen's classification, the climate is classified as semiarid, with average annual rainfall of $770 \mathrm{~mm}$ and rains irregularly distributed in the period from February to May, reaching maximum values in March and April. The dry period lasts from July to December, with lower rainfall in October and November.

Irrigation water productivity $\left(\mathrm{WP}_{\mathrm{IR}}\right)$ was calculated by the relationship between crop yield and the total volume of irrigation water applied during the crop cycle, in annual crops, or the total water applied in an annual cycle of irrigation, in semi-perennial crops.

In the present study, $\mathrm{WP}_{\mathrm{IR}}$ was also calculated in monetary terms per unit of water volume applied. In regions where precipitation is little significant, or there is scarcity of water for agriculture, with no land restriction, the goal of the farmer is to maximize net revenue per unit of irrigation water volume.

Primary data of irrigation water productivity with papaya crop were obtained in two experimental units installed in the Curu-Pentecoste Irrigated Perimeter, one irrigated by straight, open-end furrows with water from the canal and another irrigated by micro-sprinklers with water from the reuse of the surplus of furrow-irrigated areas. Table 1 shows the results of water analyses for the water sources used.

For pumpkin crop, secondary data were obtained from studies previously carried out in experimental units also located in the Curu-Pentecoste Irrigated Perimeter to calculate irrigation water productivity: the first unit with furrow irrigation and water from the canal; the second unit with drip irrigation and water from shallow well (depth less than $20 \mathrm{~m}$ ); and the third unit with drip irrigation and water from the reuse of the surplus of furrow-irrigated areas.

To determine the support capacity, which corresponds to the maximum area to be irrigated in a given working day, for irrigation using shallow wells, the shallow tube wells located in the Curu-Pentecoste Irrigated Perimeter were recorded and mapped in order to identify the largest number of wells representative of the area and obtain information about their building, lithological and hydrogeological characteristics, as well as generate basis for monitoring the temporal evolution and spatial distribution of water works in the Curu-Pentecoste Irrigated Perimeter.

Pumping tests with three flow rates were performed to determine the flow rates of the shallow wells. The variation of drawdown and the specific capacity with the increase in flow rate were used to select the optimal pumping flow, which is obtained when the well reaches a drawdown of $2 / 3$ of its initial hydraulic load.

Six wells were selected for detailed evaluation of the support capacity because they were the only ones which had flow rate data for the year of their constructions. The information regarding the shallow wells, which have depths ranging

Table 1. Chemical attributes of water from the water sources used for papaya cultivation: canal and reuse, in the Curu-Pentecoste Irrigated Perimeter

\begin{tabular}{|c|c|c|c|c|c|c|c|c|c|c|c|c|c|}
\hline \multirow{2}{*}{ Source } & \multicolumn{5}{|c|}{ Cations (mmol $\mathrm{L}^{-1}$ ) } & \multicolumn{5}{|c|}{ Anions (mmol $\mathrm{L}^{-1}$ ) } & \multirow{2}{*}{$\begin{array}{c}E C \\
\left(\mathrm{dS} \mathrm{m}^{-1}\right)\end{array}$} & \multirow{2}{*}{$\begin{array}{c}\text { SAR } \\
(\mathrm{mmol} \mathrm{L}) 0^{-5}\end{array}$} & \multirow{2}{*}{$\mathrm{pH}$} \\
\hline & $\mathrm{Ca}^{2+}$ & $\mathrm{Mg}^{2+}$ & $\mathrm{Na}^{+}$ & $\mathrm{K}^{+}$ & $\Sigma$ & $\mathrm{Cl}^{-}$ & $\mathrm{SO}_{4}{ }^{2-}$ & $\mathrm{HCO}_{3}^{-}$ & $\mathrm{CO}_{3}{ }^{2-}$ & $\bar{\Sigma}$ & & & \\
\hline Canal & 2.3 & 2.1 & 4.8 & 0.2 & 9.4 & 5.4 & 0.8 & 2.6 & 0.0 & 8.8 & 0.81 & 3.2 & 8.0 \\
\hline Reuse & 2.2 & 2.8 & 3.1 & 0.2 & 8.3 & 4.4 & 0.0 & 3.8 & 0.0 & 8.2 & 0.82 & 2.0 & 7.3 \\
\hline
\end{tabular}


between 6.0 and $10.0 \mathrm{~m}$, static levels ranging from 0.8 to $3.2 \mathrm{~m}$ and dynamic levels from 1.9 to $5.6 \mathrm{~m}$, is from the year 2002 . The flows rates were greater than $17 \mathrm{~m}^{3} \mathrm{~h}^{-1}$, with a mean value of $25 \mathrm{~m}^{3} \mathrm{~h}^{-1}$, according to the information contained in Table 2 .

Economic analysis was performed at irrigated plot level, including the scenarios shown in Table 3, which suggest alternatives to replace furrow-irrigated banana.

The economic analysis was conducted using the profitability indicators of the investment analysis (benefit/cost ratio, B/C, net present value, NPV, and internal rate of return, IRR), in addition to the payback period (PB). The comparative analysis of the profitability indicators of the investment analysis was performed for a six-year horizon, because of the economic useful life of banana, which is the most long-lived among the crops of the cropping plan.

For the area implemented with pumpkin cultivation, as it is an annual crop, two other crops were incorporated during the year, maize cultivated from February to April and cowpea from August to October, traditional crops in the Irrigated Perimeter, with water management based on the no-deficit irrigation strategy.

In the scenarios analyzed, it was considered that the farmer obtained financing for investment and inputs from Banco do Nordeste, through the credit line called Pronaf Agricultor Familiar. The conditions for amortization of the obtained financing established by the program recommend for

Table 2. Identification, location and flow rate data obtained in the period of installation of the shallow wells in the CuruPentecoste Irrigated Perimeter in 2002

\begin{tabular}{ccccc}
\multirow{2}{*}{ Wells } & \multirow{2}{*}{ Reference } & \multicolumn{2}{c}{ Coordinates } & Flow rate \\
\cline { 3 - 4 } & Longitude & Latilude & $\left(\mathbf{m}^{\mathbf{3}} \mathbf{h}^{-1} \mathbf{)}\right.$ \\
P1 & Sector C & $39^{\circ} 18^{\prime} 10^{\prime \prime} \mathrm{W}$ & $3^{\circ} 47^{\prime} 25^{\prime \prime} \mathrm{S}$ & 27.20 \\
P2 & Sector C & $39^{\circ} 19^{\prime} 22^{\prime \prime} \mathrm{W}$ & $3^{\circ} 48^{\prime} 16^{\prime \prime} \mathrm{S}$ & 32.60 \\
P3 & Sector C & $39^{\circ} 19^{\prime} 29^{\prime \prime} \mathrm{W}$ & $3^{\circ} 47^{\prime} 54^{\prime \prime} \mathrm{S}$ & 17.50 \\
P4 & Sector D & $39^{\circ} 19^{\prime} 07^{\prime \prime} \mathrm{W}$ & $3^{\circ} 48^{\prime} 00^{\prime \prime} \mathrm{S}$ & 18.00 \\
P5 & Sector D & $39^{\circ} 18^{\prime} 43^{\prime \prime} \mathrm{W}$ & $3^{\circ} 47^{\prime} 50^{\prime \prime} \mathrm{S}$ & 43.00 \\
P6 & Sector D & $3^{\circ} 18^{\circ} 07^{\prime \prime} \mathrm{W}$ & $3^{\circ} 47^{\prime} 33^{\prime \prime} \mathrm{S}$ & 16.80 \\
\hline
\end{tabular}

Table 3. Scenarios of cropping plans and irrigation methods as an alternative to replace furrow-irrigated banana in the Curu-Pentecoste Irrigated Perimeter

\begin{tabular}{cccccc}
\hline \multirow{2}{*}{ Scenario } & \multicolumn{3}{c}{ Papaya } & & \multicolumn{2}{c}{ Pumpkin } \\
\cline { 2 - 3 } \cline { 5 - 6 } & $\begin{array}{c}\text { Area } \\
\text { (ha) }\end{array}$ & $\begin{array}{c}\text { Irrigation } \\
\text { system }\end{array}$ & & $\begin{array}{c}\text { Area } \\
\text { (ha) }\end{array}$ & $\begin{array}{c}\text { Irrigation } \\
\text { system }\end{array}$ \\
01 & 1.0 & Furrows & & - & - \\
02 & 1.0 & Localized (Reuse) & & - & - \\
03 & - & - & & 1.0 & Furrows $^{*}$ \\
04 & - & - & & 1.0 & Localized (Reuse) $^{*}$ \\
05 & - & - & 1.0 & Localized (Well) $^{*}$ \\
\hline * Adding the cultivation of maize (rainfed) and cowpea (irrigation)
\end{tabular}

investments a deadline of up to 10 years, with a grace period of up to three years and interest rates ranging from $1 \%$ per year for a contracted value of up to R $\$ 10,000$ and $2 \%$ per year for $\mathrm{R} \$ 10,000$ to $\mathrm{R} \$ 50,000$.

Financial benefits consisted of the revenues from the commercialization of the production in the local market, with prices updated for the same agricultural year: $\mathrm{R} \$ 0.35 \mathrm{~kg}^{-1}$ for papaya, $\mathrm{R} \$ 0.50 \mathrm{~kg}^{-1}$ for pumpkin and $\mathrm{R} \$ 0.30 \mathrm{~kg}^{-1}$ for banana.

Fixed or investment-related costs comprised the costs of installing a shallow tube well, plus the cost related to the acquisition and installation of the localized irrigation system. Costs related to the value of the land were not considered. Variable costs were composed of the costs of crop production, including costs with labor and irrigation, which are composed of labor and payment of the water tariff $\mathrm{K}_{2}$, in furrow irrigation. The localized systems were irrigated with shallow well water and reuse water from the excess of furrow irrigation, which has no form of charging by the Irrigation District.

The profitability indicators of the investment analysis were calculated based on the updated values of costs and revenues for each of the scenarios evaluated.

\section{Results AND Discussion}

Table 4 contains the values of water productivity for banana, papaya and pumpkin crops, considering furrow and localized irrigation systems, with three water sources (canal, shallow well and reuse).

It can be seen that the banana crop irrigated by the traditional furrow system used by farmers was the scenario with largest volume of water applied per unit of area during a cycle and lowest value of irrigation water productivity, obtaining a gross value of the production of $\mathrm{R} \$ 0.29 \mathrm{~m}^{-3}$ of water applied in the crop.

The current water charging system in federal public irrigated perimeters that practice surface irrigation, under the responsibility of the Departamento Nacional de Obras Contra as Secas (DNOCS), does not encourage the practice of rational water use by farmers, as it is based on irrigated area and not on the water volume effectively used in irrigation. In Spain, for instance, Playán \& Mateos (2006) found that management techniques to reduce the excessive application of water in certain crops were encouraged in large and old Irrigation Districts and, as a result, they obtained considerable water savings, with minimal impact on crop yield, only with the guidance and re-education of farmers.

In view of the above, in order to increase water productivity and achieve the water security of a project, a fundamental

Table 4. Values of water productivity $\left(\mathrm{WP}_{\mathrm{IR}}\right)$ for the different crops studied and irrigation systems in the Curu-Pentecoste Irrigated Perimeter

\begin{tabular}{|c|c|c|c|c|c|c|}
\hline Crop & $\begin{array}{l}\text { Irrigation } \\
\text { method }\end{array}$ & $\begin{array}{l}\text { Water } \\
\text { source }\end{array}$ & $\begin{array}{c}\text { Crop yield } \\
\left(\mathrm{kg} \mathrm{ha}^{-1}\right)\end{array}$ & $\begin{array}{l}\text { Irrigation water volume } \\
\text { per area }\left(\mathrm{m}^{3} \mathrm{ha}^{-1}\right)\end{array}$ & $\begin{array}{c}W P_{\mathrm{IR}} \\
\left(\mathrm{kg} \mathrm{m}^{-3}\right)\end{array}$ & $\begin{array}{c}\text { WP } \\
\left(R_{I R} m^{-3}\right)\end{array}$ \\
\hline Banana & Surface & Canal & $10,800.0$ & $11,316.0$ & 1.0 & 0.29 \\
\hline Papaya & Surface & Canal & $42,697.0$ & $6,396.0$ & 6.7 & 2.34 \\
\hline Papaya & Localized & Reuse & $57,940.0$ & $5,413.4$ & 10.7 & 3.75 \\
\hline Pumpkin & Surface & Canal & $10,296.4$ & $6,645.0$ & 1.5 & 0.77 \\
\hline Pumpkin & Localized & Reuse & $17,549.3$ & 938.2 & 18.7 & 9.35 \\
\hline Pumpkin & Localized & Well & $25,365.0$ & 976.9 & 26.0 & 12.98 \\
\hline
\end{tabular}


change is necessary in the current waste of the production patterns of irrigated agriculture, and it is possible to increase the yields of most crops by 10 to $30 \%$ and, at the same time, reduce water use by up to $30 \%$ only with the adoption of appropriate strategies in irrigation management (Marouelli \& Calbo, 2009).

The comparative analysis of a scenario considering exclusively the values of economic productivity of irrigation water in terms of monetary unit by volume of water applied demonstrates that the replacement of furrow-irrigated banana cultivation with papaya cultivation under the same irrigation system would promote a $700 \%$ increase in water productivity. It is worth pointing out that, although the net water requirements of the two crops are similar, the values contained in this study refer to the water depths actually applied by irrigators.

According to Frizzone (2014), improving water productivity requires much more than exploiting only water management; instead, a set of other factors should be addressed, such as use of improved cultivar, soil fertility management and cultural practices that influence yield. In this study, the improvement in water productivity was observed through the replacement of crops and irrigation methods, in addition to the reuse of water.

The data showed that the change in the irrigation method led to a $36 \%$ increase in papaya yield in the Curu-Pentecoste Irrigated Perimeter, besides a $15 \%$ reduction in the volume of water applied per unit area, through the replacement of furrow irrigation with localized irrigation. It is worth noting that this change, with water from reuse in papaya cultivation, promoted a reduction in the applied water volume sufficient to meet the water need for one cycle of pumpkin cultivation in one hectare irrigated by the localized method.

For pumpkin cultivation, crop yield increments of 70 and $146 \%$ were obtained with localized irrigation with reuse water and well water, respectively, compared to pumpkin cultivation under furrow irrigation. On the other hand, the reduction in the volume of water applied in the cultivation of pumpkin, irrigated by a localized system with water sources of reuse and well, was of the order of $86 \%$ when compared to furrow irrigation. Therefore, replacing one hectare of furrow-irrigated pumpkin with localized irrigation would promote saving of approximately $5700 \mathrm{~m}^{3}$, which would enable the irrigation by localized system of one hectare with papaya for one production cycle or even 6.8 ha of pumpkin with localized system.

According to Udias et al. (2018), improving water management requires the efficient use of water for irrigation, with a view to increasing or maintaining yields with lower water volume, through irrigation technologies, avoiding losses and increasing system efficiency, or increasing water productivity. In the current reality of the Curu-Pentecoste Irrigated Perimeter, however, there is a lack of modernization in the production structure and technical assistance for adjusting the best management to be used; in addition, there is no flexibility in the water delivery calendar. With the change of irrigation method only, there was an increase of approximately $60 \%$ in the water productivity in the papaya crop.

The pumpkin crop showed better water productivity when the surface irrigation method was converted to localized irrigation (Table 4). However, when considering only the replacement of the banana crop, maintaining the surface irrigation system, the papaya crop had greater technical viability based on the obtained values of water productivity.

According to Castro et al. (2007), the productivity reached under irrigated regime in the Curu-Pentecoste Irrigated Perimeter is lower than what could actually be obtained with more appropriate irrigation management by the farmers.

The results of the production tests for the shallow tube wells located in the Curu-Pentecoste Irrigated Perimeter for the years 2002 and 2013 are presented in Table 5.

The variation in flow rate values for the same year of analysis is attributed to the characteristics of the lithological profile of the respective wells. Taking as reference the production tests in the wells evaluated in 2013 (P1 and P4), it is possible to observe the relationship between flow rate and lithological profile of the soil. While the P1 well, which showed the highest flow rate, has a soil layer of sand-sized granules with small pebbles, the $\mathrm{P} 4$ well, which showed unfavorable performance, has formation of clayey soil.

In the evaluation of wells with production tests in 2002 and 2013, there was a temporal reduction in the flow rates. Two aspects must be considered in this analysis: the current period of scarcity of aquifer recharge and the period in which the production tests were carried out. The production tests in 2002 were performed between February and April, which belong to the rainy quarter, while the tests carried out in 2013 occurred from October to December, thus at the end of the dry season.

Table 6 lists the values of support capacity, in hectare, for irrigation using shallow tube wells located in the hydraulic sectors C and D of the Curu-Pentecoste Irrigated Perimeter, considering a specific or unit flow rate of $1.15 \mathrm{~L} \mathrm{~s}^{-1} \mathrm{ha}^{-1}$ (corresponding to a daily water depth of $9.94 \mathrm{~mm}$ ) for localized irrigation.

Considering that the production tests of the three wells studied in 2013 were performed during the dry period, the

Table 5. Flow rates of the shallow wells in the years 2002 and 2013

\begin{tabular}{|cccc|}
\hline \multirow{2}{*}{ Wells } & Reference & \multicolumn{2}{c|}{ Flow rate $\left(\mathbf{m}^{\mathbf{3}} \mathbf{h}^{-1}\right)$} \\
\cline { 3 - 4 } P1 & Sector C & 2002 & $\mathbf{2 0 1 3}$ \\
P2 & Sector C & 32.6 & 16.5 \\
P3 & Sector C & 17.5 & 11.9 \\
P4 & Sector D & 18.0 & 4.8 \\
P5 & Sector D & 43.0 & ${ }^{* *}$ \\
P6 & Sector D & 16.8 & ${ }^{* * *}$ \\
\hline
\end{tabular}

${ }^{\star}$ Dry well; ${ }^{* *}$ Earth-filled well; ${ }^{* * *}$ Well with static level too low for performing the production test

Table 6. Support capacity of shallow wells in the CuruPentecoste Irrigated Perimeter for the condition of irrigation with free demand and $12-\mathrm{h}$ period

\begin{tabular}{|ccccc}
\hline \multirow{2}{*}{ Wells } & Reference & $\begin{array}{c}\text { Flow rate } \\
\left(L^{-1}\right)\end{array}$ & Area $^{*}$ & Area $^{* *}$ \\
\cline { 4 - 5 } & & & \multicolumn{2}{c}{ (ha) } \\
P1 & Sector C & 7.6 & 6.6 & 3.3 \\
P3 & Sector C & 4.9 & 4.2 & 2.1 \\
P4 & Sector D & 5.0 & 4.3 & 2.2 \\
\hline & & & 2002 & \\
P1 & Sector C & 4.58 & 4.0 & 2.0 \\
P3 & Sector C & 3.31 & 2.9 & 1.4 \\
P4 & Sector D & 1.33 & 1.2 & 0.6 \\
\hline
\end{tabular}

* Free demand $(24 \mathrm{~h}) ;{ }^{* *} 12$-h period 
total support capacity for irrigation was 4.0 ha, with average of 1.4 ha per well, in a daily irrigation period of $12 \mathrm{~h}$. It is also observed that the area served by each shallow well is less than 4.0 ha, an area characterized as a standard lot for farmers of the Curu-Pentecoste Irrigated Perimeter.

Silveira et al. (2016), in a study in the Curu-Pentecoste Irrigated Perimeter, concluded that the alluvial aquifer showed sensitivity to climatic conditions, since the main source of recharge is rainfall. The study also pointed out the importance of groundwater from the alluvial aquifer and the need for inserting this resource in the decisions and implementations of legal instruments for the effective integrated management of water resources.

The economic indicators for all scenarios proposed to replace surface-irrigated banana crop are presented in Table 7.

It can be observed that all scenarios of cropping plans and irrigation methods with alternative water sources had positive NPV and IRR higher than the discount rate of $2 \%$ (Pronaf), even for banana crop under surface irrigation currently implemented in the Curu-Pentecoste Irrigated Perimeter, and this scenario in particular was the one which had the most unfavorable performance compared to the others evaluated.

The highest net revenues obtained were recorded in areas cultivated with pumpkin under localized irrigation, despite having the highest investment costs. The pumpkin crop under localized irrigation using shallow well was the scenario that had the highest net present value ( $\mathrm{R} \$ 63,245.47$ ).

All values referring to the $\mathrm{B} / \mathrm{C}$ ratio were higher than the unit, that is, expected benefits greater than the costs, indicating that the analyzed projects are economically viable. However, the greater this relationship, the more economically indicated the project, and the most favorable results were obtained for scenarios 5, 4 and 2 .

The IRR ranged from $23.7 \%$ for surface-irrigated banana to $80.1 \%$ for the implementation of pumpkin cultivation under localized irrigation using water from shallow well, meaning that the capital allocated in the project supports an increase in the discount rate up to these respective values per year, for each year of the analysis horizon of the project. Under these conditions, the investment will be unfeasible only if the average market interest rate reaches values higher than those of the respective IRR.

Considering that the economic viability of introducing new crops and implementing localized irrigation must necessarily go through the increase in the net benefit resulting from these

Table 7. Net present value (NPV), benefit/cost ratio (B/C), internal rate of return (IRR) and payback period (PB) for each cropping scenario studied

\begin{tabular}{lrrrc}
\hline \multirow{2}{*}{ Scenarios $^{*}$} & \multicolumn{4}{c|}{ Indicators } \\
\cline { 2 - 5 } & NPV (R\$) & B/C & IRR (\%) & PB (years) \\
\hline Banana & $4,812.83$ & 1.34 & 23.7 & 2.34 \\
Scenario 1 & $21,989.04$ & 1.87 & 60.3 & 1.13 \\
Scenario 2 & $29,071.95$ & 1.99 & 62.9 & 1.03 \\
Scenario 3 & $24,271.65$ & 1.82 & 48.1 & 1.70 \\
Scenario 4 & $42,452.65$ & 2.33 & 61.8 & 1.46 \\
Scenario 5 & $63,245.47$ & 2.92 & 80.1 & 1.19 \\
\hline
\end{tabular}

* Scenario 1 - Papaya (Surface); Scenario 2 - Papaya (Localized/Reuse); Scenario

3 - Pumpkin + Maize + Cowpea (Surface); Scenario 4 - Pumpkin + Maize + Cowpea

(Localized/Reuse); Scenario 5 - Pumpkin + Maize + Cowpea (Localized/Well) steps, the enterprise is economically viable only when the increase in revenue exceeds the increase in costs caused by the proposed changes.

According to Costa et al. (2016), returns from an investment will occur for several years and it is of fundamental importance that the profitability analysis be carried out in the long term. For the pumpkin crop, for instance, in an analysis of the economic profitability of production in the São Francisco region, Araújo \& Correia (2010) concluded based on the variables of economic performance studied that the cultivation of this crop is a profitable activity, with a record of substantial figures for the region. The study also reveals that crop management predominantly carried out manually, a situation corresponding to the segment of small family production, with significant social value, which is also valid for this study.

\section{Conclusions}

1. Low water productivity in traditional, furrow-irrigated banana cultivation justifies its replacement in the cropping plan.

2. Shallow wells, even in conditions of water scarcity, have the capacity to support the irrigation of areas corresponding to the lots of small producers.

3. The scenarios analyzed in this study are economically viable alternatives for replacing the banana crop.

\section{ACKNOWLedgments}

The present study was conducted with support from Coordenação de Aperfeiçoamento de Pessoal de Nível Superior - Brasil (CAPES) - Funding Code 001.

\section{Literature Cited}

Araújo, J. L. P.; Correia, R. C. Análise dos custos de produção e da rentabilidade do sistema típico de produção da abóbora na região do Submédio São Francisco. In: Congresso da Sociedade Brasileira de Sistemas de Produção, 8, 2010, São Luís. Anais... São Luís: UEMA, 2010. CD Rom.

Bonini, M. de A.; Sato, L. M.; Bastos, R. G.; Souza, C. F. Alterações nos atributos químico e físicos de um Latossolo Vermelho irrigado com água residuária e vinhaça. Revista Biociências, v.20, p.7885, 2014. http://periodicos.unitau.br/ojs/index.php/biociencias/ article/view/1817/1521

Castro, R. P.; Costa, R. N. T.; Silva, L. A. C.; Gomes Filho, R. R. Modelos de decisão para otimização econômica do uso da água em áreas irrigadas da Fazenda Experimental Vale do Curu, Pentecoste - CE. Irriga, v.12, p.377-392, 2007. http://dx.doi.org/10.15809/ irriga.2007v12n3p377-392

Costa, R. N. T.; Lacerda, C. F. de; Silva, L. A. C. da; Araújo, A. P. B. de; Araújo, J. C. de; Sousa, C. H. C. de. Indicadores de rentabilidade da recuperação de solos degradados por sais. In: Gheyi, H. R.; Dias, N. da S.; Lacerda, C. F. de; Gomes Filho, E. (eds.). Manejo da salinidade na agricultura: Estudos básicos e aplicados. Fortaleza: INCTSal, 2016. Cap.29, p.479-488. 
Dantas, I. L. de A.; Faccioli, G. G.; Mendonça, L. C.; Nunes, T. P.; Viegas, P. R. A.; Santana, L. O. G. de. Viabilidade do uso de água residuária tratada na irrigação da cultura do rabanete (Raphanus sativus L.). Revista Ambiente \& Água, v.9, p.109-117, 2014. http:// dx.doi.org/10.4136/ambi-agua.1220

Frizzone, J. A. Eficiência e uniformidade da irrigação: Possibilidades técnicas e econômicas para melhoria. In: Frizzone, J. A.; Lima, S. C. R. V.; Costa, R. N. T. (eds.). Irrigação: Da conservação de água e solo à sustentabilidade com vistas à autogestão. Fortaleza: Inovagri, 2014. Cap.2, p.35-78.

Leuther, F.; Weller, U.; Wallach, R.; Vogel, H. J. Quantitative analysis of wetting front instabilities in soil caused by treated waste water irrigation. Geoderma, v.319, p.132-141, 2018. https://doi. org/10.1016/j.geoderma.2018.01.004

Malek, K.; Adam, J. C.; Stöckle, C. O.; Peters, R. T. Climate change reduces water availability for agriculture by decreasing nonevaporative irrigation losses. Journal of Hydrology, v.561, p.444460, 2018. https://doi.org/10.1016/j.jhydrol.2017.11.046

Marouelli, W. A.; Calbo, A. G. Manejo de irrigação em hortaliças com sistema Irrigas. 5.ed. Brasília: Embrapa Hortaliças, 2009. 16p. Circular Técnica, 69

Nunes, K. G.; Costa, R. N. T.; Cavalcante Júnior, J. A. H.; Araújo, D. F. de. Comportamento da alface-americana sob diferentes doses de composto orgânico e lâminas de irrigação. Irriga, v.22, p.167176, 2017. http://dx.doi.org/10.15809/irriga.2017v22n1p167-176
Perry, C.; Steduto, P.; Allen, R. G.; Burt, C. M. Increasing productivity in irrigated agriculture: Agronomic constraints and hydrological realities. Agricultural Water Management, v.96, p.1517-1524, 2009. https://doi.org/10.1016/j.agwat.2009.05.005

Playán, E.; Mateos, L. Modernization and optimization of irrigation systems to increase water productivity. Agricultural Water Management, v.80, p.100-116, 2006. https://doi.org/10.1016/j.agwat.2005.07.007

Rebouças, J. R. L.; Dias, N. da S.; Gonzaga, M. I. da S.; Gheyi, H. R.; Sousa Neto, O. N. de. Crescimento do feijão-caupi irrigado com água residuária de esgoto doméstico tratado. Revista Caatinga, v.23, p.97-102, 2010. https://periodicos.ufersa.edu.br/index.php/ caatinga/article/view/1506

Silveira, R. N. C. M.; Costa, R. N. T. C.; Peixoto, F. da S.; Sousa, H. G. de; Cavalcante, I. N.; Oliveira, R. M. de. Reservas hídricas subterrâneas e contribuição à gestão dos recursos hídricos em aluviões no semiárido. Geociências, v.35, p.642-651, 2016. http:// www.ppegeo.igc.usp.br/index.php/GEOSP/article/view/9977

Udias, A.; Pastori, M.; Malago, A.; Vigiak, O.; Nikolaidis, N.; Bouraoui, F. Identifying efficient agricultural irrigation strategies in Crete. Science of the Total Environment, v.633, p.271-284, 2018. https:// doi.org/10.1016/j.scitotenv.2018.03.152

Vergine, P.; Salerno, C.; Libutti, A.; Beneduce, L.; Gatta, G.; Berardi, G.; Pollice, A. Closing the water cycle in the agro-industrial sector by reusing treated wastewater for irrigation. Journal of Cleaner Production, v.164, p.587-596, 2017. https://doi.org/10.1016/j. jclepro.2017.06.239 